\title{
Views on an active learning curriculum improving knowledge
}

This article was published in the following Dove Press journal:

Advances in Medical Education and Practice

21 August 2017

Number of times this article has been viewed

\author{
Mariam Salaria \\ School of Medicine, University of \\ Liverpool, Liverpool, UK
}

\section{Dear editor}

I read with great interest the article by Inra et al, ${ }^{1}$ regarding an active learning curriculum, to improve knowledge and teaching skills. Having completed four years at Liverpool Medical School, I agree that an active learning curriculum is both stimulating and productive for medical students. The article states that an active learning curriculum is preferred by Gastroenterology Fellows and may be helpful for improving transmission of information, in any specialty. Therefore, active learning could perhaps be applicable for students and influence future curriculums.

The study does suggest that traditional lectures allow teachers to convey matter in a small period of time, although it also implies that active learning may lead to better conceptual understanding development of problem-solving skills. Conceptual understanding and skill development are fundamental in all roles of health professionals, suggesting that active learning is imperative. What is more, it states that active learning requires students to be proactive and to analyze, and evaluate information, as well as attempt to solve problems. ${ }^{1}$ Problem solving is a skill that is particularly important for future doctors, as highlighted by Rogers et al. ${ }^{2}$ Not only did Inra et al ${ }^{1}$ show that Gastroenterology Fellows preferred the new active learning curriculum, but they also conveyed that the doctors found the sessions engaging, and educationally stimulating.

Conversely, White et $\mathrm{al}^{3}$ have found that medical students are actually "checking out" of active learning in their curriculum. This implies that perhaps active learning is not productive in improving knowledge. Although, it is important to take into account the study groups. The latter was conducted on medical students, whereas Gastroenterology Fellows were used by Inra et al. ${ }^{1}$ Perhaps, an older population may find active learning more stimulating. Comparingly, it was found that medical students might need explicit assistance in appreciating the value of an adult learning, and an active curriculum, or that they might not be developmentally ready for it.

To conclude, active learning is thought to improve knowledge in a variety of ways, and has been proven to do so. ${ }^{1}$ However, active learning may only be applicable to older members of the medical profession as students do not appear to appreciate it. Perhaps, methods should be taken to introduce active learning at a slower rate for medical students.

\section{Disclosure}

The author reports no conflicts of interest in this communication. 


\section{References}

1. Inra JA, Pelletier S, Kumar NL, Barnes EL, Shields HM. An active learning curriculum improves fellows' knowledge and faculty teaching skills. Adv Med Educ Pract. 2017;8:359-364.
2. Rogers JC, Swee DE, Ullian JA. Teaching medical decision making and students clinical problem solving skills. Med Teach. 1991;13(2):157-164.

3. White C, Bradley E, Martindale J, et al. Why are medical students 'checking out' of active learning in a new curriculum? Med Educ. 2014;48(3): $315-324$. 


\section{Authors' reply}

Jennifer A Inra',2

Stephen Pelletier ${ }^{2}$

Navin L Kumar ${ }^{1,2}$

Edward L Barnes 3,4

Helen M Shields ${ }^{1,2}$

'Division of Gastroenterology, Hepatology and Endoscopy, Brigham and Women's Hospital, ${ }^{2}$ Harvard Medical School, Boston, MA, ${ }^{3}$ Division of Gastroenterology and Hepatology, University of North Carolina, ${ }^{4}$ University of North Carolina School of Medicine, Chapel Hill, NC, USA

Correspondence: Jennifer A Inra

Department of Medicine, Harvard

Medical School, Brigham and Women's

Hospital, 75 Francis Street, ASB2, Boston,

MA 02115 , USA

Tel + I 6177326389

$\mathrm{Fax}+16179780840$

Email jinra@partners.org

\section{Dear editor}

We appreciate the thoughtful comments we received regarding our article "An active learning curriculum improves fellows' knowledge and faculty teaching skills".

The article by White et $\mathrm{al}^{2}$ discusses various reasons why medical students may have "checked out" during a new flipped classroom preclinical curriculum. Several of these obstacles are addressed by our curriculum. In White et al's article, the class was structured with 18 tables on which sat up to nine students. The room was large enough such that students could "hide" in the back of the room to avoid participating. In addition, students remarked that they often chose to sit with friends, which allowed them to feel less pressure to prepare for class and also allowed them to engage in social conversation with friends. Our sessions, in contrast, took place in a small conference room around one large table. Even though fellows may have been sitting with friends, all were sitting in close proximity to the speaker, which prevented social side conversations and did not allow anyone to "hide" in the back of the room.

The students in White et al's article also reported that they were "checking out" when they felt sessions were not well designed, or poorly executed and inefficient. These comments stress the importance of faculty development, or faculty coaching, both of which were integral to the success of our curriculum.

We agree that some of the differences seen between our study and White et al study regarding the value of an active learning curriculum may be due to the academic maturity study groups, as Salaria suggests. White et al conclude that medical students may need help in appreciating the value of, or may not be developmentally ready for, an active curriculum. Our Gastroenterology Fellows, on the other hand, are clearly ready and are embracing this educational teaching shift.

\section{Disclosure}

The authors report no conflicts of interest in this communication.

\section{References}

1. Inra JA, Pelletier S, Kumar NL, Barnes EL, Shields HM. An active learning curriculum improves fellows' knowledge and faculty teaching skills. Adv Med Educ Pract. 2017;8:359-364.

2. White C, Bradley E, Martindale J, et al. Why are medical students 'checking out' of active learning in a new curriculum? Med Educ. 2014;48(3):315-324.

Dove Medical Press encourages responsible, free and frank academic debate. The content of the Advances in Medical Education and Practice 'letters to the editor' section does not necessarily represent the views of Dove Medical Press, its officers, agents, employees, related entities or the Advances in Medical Education and Practice editors. While all reasonable steps have been taken to confirm the content of each letter, Dove Medical Press accepts no liability in respect of the content of any letter, nor is it responsible for the content and accuracy of any letter to the editor.

\section{Publish your work in this journal}

Advances in Medical Education and Practice is an international, peerreviewed, open access journal that aims to present and publish research on Medical Education covering medical, dental, nursing and allied health care professional education. The journal covers undergraduate education, postgraduate training and continuing medical education including emerging trends and innovative models linking education, research, and health care services. The manuscript management system is completely online and includes a very quick and fair peer-review system. Visit http://www.dovepress.com/testimonials.php to read real quotes from published authors. 